\title{
Ecopoetic Elements in the Work of Sarah Kirsch, Ahmed Rashid Thani, and Derek Walcott
}

\begin{abstract}
Comparative analyses of poetry by the German Sarah Kirsch, the Emirati Ahmed Rashid Thani, and the St Lucian Derek Walcott identify three distinct ecopoetic elements their work has in common. The three poets, born before the origin of ecocriticism, favour metaphors that represent natural landscapes. These metaphors express a certain "nature-centrism," and explicit references to environmental threats provoke approaches informed by ecocriticism to the oeuvres of all three poets alike. While the analyses highlight stylistic and culture-related differences, they manifest the urgency of an awareness for the global in the context of sustainability.
\end{abstract}

Keywords: Ahmed Rashid Thani (أحمد راشد ثناني), Derek Walcott, ecocriticism, ecopoetry, Sarah Kirsch

Sarah Kirsch, Ahmed Rashid Thani (أحمد راشد ثاني), and Derek Walcott are not typical examples of ecopoets. Neither of them feature in collections such as Ann Fisher-Wirth and Laura-Gray Street's extensive Ecopoetry Anthology (2015b). Much of Walcott's, Kirsch's, and Thani's work originated before ecocritical discourse became popular in literary studies. Nevertheless, ecopoetic elements dominate the work of all these twentieth-century authors alike, and the present comparative analysis identifies three such elements their oeuvres share. Firstly, the three poets favour metaphors that represent natural landscapes. Secondly, these metaphors often express what Yee-mun Park has defined as "nature-centrism" (Han 2012, 105) in contrast to concepts of "biocentrism" or "ecocentrism" referred to in anglophone ecocritical scholarship. Thirdly, explicit references to environmental threats provoke ecocritical readings of all three poets' oeuvres alike.

The selection of authors from three different continents further emphasizes the urgency of what Ursula K. Heise prominently termed "sense of planet" in the context of ecocritical discourse (Heise 2008, 12). Judging by the extraordinary amount of recent research in the field by scholars from across the globe, this concept has made its due impact, at least in the academic sphere. Each of the three sections of the present essay focuses on one of the three poets, beginning with Kirsch from Germany, continuing with Thani from the United Arab Emirates, 
and closing with possibly the best known of the three, Walcott from St Lucia. The comparative analysis highlights stylistic differences, such as Gothic features in poems by Kirsch, and a passion for self-reflexivity in texts by Walcott. Thani best illustrates a merging of the speaker with his or her natural environment.

Ecocriticism became an increasingly popular approach within literary and cultural studies during the second half of the twentieth century. Cheryl Glotfelty and Harold Fromm provide an extensive resource for North American scholarship in The Ecocriticism Reader: Landmarks in Critical Ecology (1996). Most of the scholarship included revolves around prose, and this fact reflects the general representation of poetry in ecocritical studies until the turn of the millennium. At least in English, Ecopoetry: A Critical Introduction, edited by J. Scott Bryson (2002b), was the first book dedicated to the genre. Unlike Bryson, I do not define ecopoetry as a "subset of nature poetry" (Bryson 2002a, 5), but the three particular characteristics identified in his introduction do correspond to the three shared elements that allow selected texts by Walcott, Kirsch, and Thani to be characterized as ecopoetry.

What Bryson describes as "humble appreciation of wildness" (2002a, 7) engenders the predominance of metaphors related to non-human nature in the work of all three poets alike. Bryson further defines ecocentrism as the "interdependent nature of the world" (2002a, 6). In the present essay, I propose to pursue the concept of doh, as employed by Jihee Han, in order to overcome the binary opposition between anthro- and ecocentrism. Bryson's third characteristic, "skepticism towards hyperrationality and its resultant overreliance on technology" (2002a, 6), underlies some of the passages from selected poems in which contemporary environmental threats become explicit.

\section{Walcott's, Kirsch's, and Thani's land- and seascapes: Apropos mudflats}

Walcott's magnum opus, Omeros, ends with the statement that, "when he left the beach, the sea was still going on" (Walcott 1990, 325). The emphasis on the sea's agency at such a crucial position in the poet's oeuvre exemplifies his obsession with maritime metaphors, which I have discussed in detail in "Geo- and Ecocritical Considerations of Derek Walcott's Multitasking, Omnipresent Sea” (Hambuch 2015). Landscapes, however, feature as prominently as seascapes not only in Walcott's, but also in Kirsch's and Thani's poetry.

Kirsch is the only one of the three who often uses a Gothic undertone in her portrayals of nature. The collection Erlkönigs Tochter [Alder King's Daughter] 
(Kirsch 1992), ${ }^{1}$ for example, includes eerie illustrations of nature's coexistence with, and survival despite, "culture." The title figure of this collection, inspired by an uncanny scenario in a famous ballad by Johann Wolfgang von Goethe (n.d. [1782]), appears in a series of three poems titled "Watt" [Mudflats]. This series contains explicit references to environmental dangers and is therefore more relevant to the concluding section of my study. The following paragraphs demonstrate Kirsch's unique Gothic renderings of non-human nature in a different poem from the same collection. Thani and Walcott, by contrast, at times present nature in a spiritual context missing from Kirsch's poetry. Walcott, furthermore, adds self-referential elements to which I return at the end of this section.

Kirsch opens "Ungewisses Licht” [Uncertain Light] (Kirsch 1992, 21) with the observation that "the ship and sea / are dreadfully vast" [Das Schiff und das Meer / Sind mörderisch groß]. During a sea passage off the Norwegian coast, the narrator observes how "the drowning sun / is thrown unto the ceiling" [Die ertrinkende Sonne / Wird an die Decke / Geworfen] inside the ship. The German word mörderisch includes a root meaning "murder," and drowning implies death. The only end rhyme of the poem evokes the dead with the German word "Toten," explicitly:

\author{
Der Fjord teilt sich in \\ Nebenfjorde da tauchen \\ Die ersten Zacken der \\ Spitzen Tannen auf vor den \\ Unersättlichen Toten \\ Unterwegs zu den \\ Berühmten Lofoten.
}

[The fjord splits into / Smaller fjords the first / Peaks of pointed pines / Appear in front of / Insatiable dead / On their way to the / Famous Lofoten.]

While the "dead" in the antepenultimate line may refer, metaphorically, to the passengers remaining on the ship, it may also refer to others who have actually drowned. The addition of "insatiable" [unersättlichen] favours the former interpretation. Arguably, insatiability among the living, resulting in consumerism and exploitation of natural resources, induces much of the damage done to the environment. In “'Die Endlichkeit dieser Erde ...' [The Limits of this Earth ...]: Sarah Kirsch's Chronicles of Transience,” Michael Butler discusses Kirsch's interest in

1 Translations are my own unless noted otherwise. The German Erle (plural Erlen) corresponds to the English alder, but comparisons with old European legends would suggest the figure to be a king of the elves (Elfenkönig). 
"the fragility of natural phenomena" (Butler 1997, 48) in the context of her prose collections. Her poetry, likewise, expresses what Butler aptly describes as a "clearsighted registration of human and natural destructiveness" (1997, 50). Frequently, the tone is beyond "melancholic" (Butler 1997, 47) and "somber" (54), downright Gothic and uncanny.

Another example of a haunting nature occurs in "Winter Field" (Kirsch 1992, 6), in which werewolves are devouring the speaker's "perforated sleep." In "Ice Land" (Kirsch 1992, 10), the air is singing "gruesome songs" in a storm, and the land appears incarcerated by the sea. Heaven is writing farewell letters in "Spring Tide” (Kirsch 1992, 11). "Conservatory I” (Kirsch 1992, 12) describes the night as "black thumping windy," and such images do not occur exclusively in Erlkönigs Tochter. There are "carcasses frozen stiff" in the fields in "Increasing Cold” (Kirsch 1982, 72). In "Beginning Destruction” (Kirsch 1982, 65), there is a bewitched meadow along with treacherous moss. In "Nightly" (Kirsch 1989, 70), there are ghosts riding on sunken rocks. In "The Flood" (Kirsch 1989, 38), there are deserted villages and dried up bogs, to list only a few of the many examples from other collections.

This is not to say, however, that all of Kirsch's representations of landscapes contain nightmarish, Gothic tones. Her poetic flora and fauna is often present and matter-of-fact in many individual titles, such as "In the Forests" (Kirsch 1989, 7), “Green Land” (9), “Air and Water” (19), “Plant’s Life” (32), “Oak Trees” (33), and "Dragonflies" (49), as well as in older titles including "Bears” (Kirsch 1982, 7), "Death Valley” (9), “Trees” (22), “The Flowers” (50), "Rocks” (74), and "Earth's Smoke” (77). Suggested images sometimes lead to unexpected conceits, and occasionally they appear pleasing and even comforting, for example as "shining light flowers” (Kirsch 1982, 57), "birds with smiling faces” (Kirsch 1989, 8), "beautiful red-blossoming morning light" (11), and "enticing wings of insects" (49). In his epilogue to Kirsch's last publication, the prose volume AEnglish, Frank Trende reports on a considerable number of writers who settled in northern Germany in the 1980s (Trende 2015, 70). He values their literary representations of the unique topography as a tribute to the region and points out that this "place-poetry" interaction was extraordinarily effective for Kirsch. Besides the North Sea landscape, Kirsch at times identifies places explored during journeys, such as Lofoten, as well as other landmarks in Scandinavia, the United Kingdom, and North America.

Kirsch was born as Ingrid Bernstein in 1935, in what would become the German Democratic Republic (East Germany). She completed a degree in biology before turning to studies in literature. She published her first volume of poetry, Gespräch mit dem Saurier (1965), together with Rainer Kirsch (see Hopwood 1997, 6). After her participation in protests against the deportation of Wolf Biermann, Kirsch received an exit visa and moved to West Berlin in 1977. Besides the many prizes 
awarded in recognition of her achievements, she also received appointments as an honorary professor at the University of Kassel (Hopwood 1997, 8) and as a visiting writer at the Centre for Contemporary German Literature at the University of Wales, Swansea (Hopwood and Basker 1997, ix). In the early 1980s, Kirsch moved to Schleswig-Holstein in northern Germany, where she died in 2013. The poet's studies in biology clearly inform her representations of flora and fauna. Their presence is obvious even in the titles of her publications, for example in Rückenwind [Tailwind] (1976), Erdreich [Soil; literally, "Riches of the Earth"] (1982), Katzenleben [Cat's Life] (1984), and Schneewärme [Heat of the Snow] (1989). Only the first of these titles signals a human presence within the said flora and fauna, a background against which to measure the direction of the wind. The others signal a holistic understanding of human culture as interwoven with a matrix of human as well as non-human nature. Such understanding characterizes the work of all three poets alike.

While the original title of one of Thani's last poetry collections, مقعد الرمل [The Sand's Seat] (2010a), does not evoke human presence explicitly, many of the poems included in this selection from several preceding publications do. "The Sea Used to Belong to Me” (Thani 2010a, 60), for example, clearly foregrounds a narrator's consciousness. In contrast to Kirsch's titles, Thani's fixate more on the sea, for example أغاني البحر ] on the Sea]. Corresponding to his origin in the United Arab Emirates, the environment in Thani's poetry generally appears different from Kirsch's. Instead of mudflats, there are sandy beaches. In a poem titled "With the Owl of My Self" (Thani 2010a, 7), a speaker is playing with "the beach's fingers," and is a few lines later seen in hiding "like a grain of sand" (8). More often than in Kirsch's texts, the lyric I merges into the landscape, a technique that will be at the centre of the following, second section of this study. This technique is evident in "Every Morning," where the speaker is lying down as "body and city” (Thani 2010a, 15) in order for "a flower to pierce my rib." In "Idol Water," hiking paths appear as bloodlines (Thani 2010a, 34). Thani favours personifications to support the sense of an active other-than-human nature, in "Dust Chats" (2010a, 64) or "The Hungry Rose” (113), for example.

Just as many passages reveal the north of Europe in Kirsch's settings, and the Arabian Peninsula features prominently in Thani's, so the Caribbean island of St Lucia provides much of the environment in Walcott's texts. The latter no doubt travelled most widely of the three throughout his long life, but most of his poems that are relevant when it comes to identifying ecopoetic elements revolve around his home island. An important feature that distinguishes Walcott's from Kirsch's and Thani's poetic representations of landscapes is self-reflexivity. Even the closing line of Omeros quoted at the beginning of this section includes this device, 
with the sea symbolizing the story, which continues as both fact and fiction. This conceit is more obvious in Another Life:

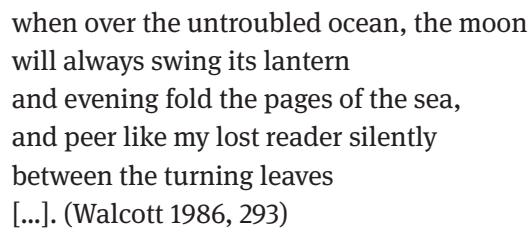

While other-than-human nature is alive and active in texts by all three poets, often supported by personifications in Thani's work, it functions as a chronicler - much like the writer himself - in Walcott's poetry. Placed in a cosmic context, as I return to in the following section, it mediates a spirituality ultimately responsible for the poet's talent on the one hand and for the continuity of stories on the other.

\section{Nature-centrism and doh: In the sand's seat}

"Ecopoetry enacts through language the manifold relationship between the human and the other-than-human," Fisher-Wirth and Street write in their preface to The Ecopoetry Anthology (2015a, xxx). I do not propose to deny the limited perspective that human consciousness faces with regard to that which lies beyond its realm. I agree with Helen Tiffin's observation that "in the case of human beings, 'landscape' becomes a form of interaction between people and their place, in large part a symbolic order expressed through representation" $(2005,199)$. It would be useless to deny the human perspective of any critical discourse, just as it would be to ignore the artist's in her or his art. Nevertheless, the concept of doh, as described by Han in her study of Yeats's poetry, may prove useful in comprehending poetic representations of human within non-human nature beyond the juxtaposition of the two realms. Taking as its starting point a brief summary of Han's argument, this second section of my essay applies the concept of "nature-centrism," entailing a holistic synthesis of human (as in anthropocentric) and non-human (as in ecocentric) nature, to selected passages from Walcott's, Kirsch's, and Thani's work. In the context of Caribbean ecocriticism, Jana Evans Braziel has compellingly used the labels "symbiotic or rhizomic" to describe this union of human and other-than-human at hand $(2005,111)$.

Han's comparative study of Yeats's Romantic ideals and landscape painting from Korea's Joseon period reveals "a modern ecological strategy that creatively fuses Western and Eastern cultural traditions and their respective appreciation of nature" (Han 2012, 103). Han understands Western "biocentrism" (or ecocen- 
trism) as inherently limited because it remains "based on the assumptions of Western metaphysics, which are fundamentally anthropocentric” $(2012,104)$. In a chapter on "die holistische Gartenkonzeption" [the holistic concept of gardens] (Wolting 2009, 179) in her study of Kirsch's poetry, Monika Wolting describes a holistic perspective similar to the one expressed by Han's doh:

Die Gedichte oszillieren um das gefährdete Gleichgewicht zwischen Mensch und Natur. [Kirschs] Lyrik vermittelt stets eine Botschaft, dass nur in der Harmonie zwischen dem Inneren und dem Äußeren der Mensch sein Glück suchen kann. (Wolting 2009, 179)

[The poems revolve around the endangered equilibrium between human and non-human nature. (Kirsch's) poetry continuously conveys a message about the fact that human beings can only search for happiness in harmony between the within and that which lies without.]

Wolting quotes Kirsch to emphasize the intention behind passages that lead to this observation. In the context of an exhibition in 1996, the poet declared that, in rejecting the label "nature poetry" for her work, she saw herself as integral part of nature ("Ich sehe mich, indem ich behaupte, keine Naturgedichte zu machen, als ein Stück der Natur”; Wolting 2009, 182). While the poet sees herself as integral part of nature, her lyric I tends to appear apart, as an observer. Thani, in contrast, emphasizes the merging of human and other-than-human nature in much of his poetry. A brilliant example for this technique occurs in "In this City," the poem from which the title of the collection The Sand's Seat is derived.

"في هذه المدينة" [In this City] begins with an aimless speaker, moving from one pub to another, suddenly entering into a dialogue with the sea. Self and nature melt into a single organism, with "a head's sky" full of "question stones" (Thani 2010a, 152). ${ }^{2}$ The poem presents a shift from dialogue between the speaker and the sea as conversation partner, to the former's integration with the latter. The following excerpt includes lines 5-9, presenting the first address of the speaker to the sea, as well as the closing eight lines illustrating their union:

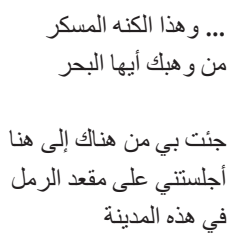

$[\ldots]$

2 My understanding of this poem owes much to the German translation by Suleman Taufiq (Thani 2010b, 90-93). 


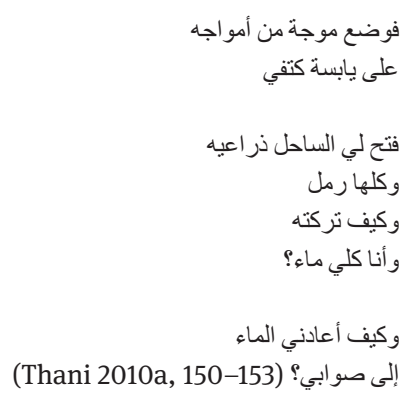

[... and who gave you / this intoxicating essence, o sea // you brought me from there to here / made me sit on the sand's seat / in this city // (...) // it placed one of its waves / around the land of my shoulder // the coast opened its arms for me / they were all sand / and how could I have left / since I was all water? // and how did the water / bring me to my senses?]

At the beginning of this poem, the speaker divides his self into consciousness and body, stating, "I carry my body from one pub to another / and it carries me." The notion of a "soul" occurs after the speaker calls on the sea, when the speaker reflects on a descent into his "depths" juxtaposed with an ascent into "the darkness of [his] soul." He sees himself oblivious to past and future, but then removes "the curtain of drunkenness / from [his] head's window." One may understand this drunkenness literally with reference to the pubs mentioned at the beginning of the poem. However, one may also interpret it as a search for revelation finally granted through a union with the sea. The realization that "I found that the hotel had distanced me / from the sea" prepares the scene for this union. The "question stones" mentioned earlier appear as steps "towards the sea." The conceit of the union succeeds as the waves receive the capacity to embrace, aided by the personified coast, which "opened its arms." The human shoulders, in turn, appear as "land" and the lyric I sees himself as "all water." This water, of sea and self, seems to endow "reason" or "common sense," although the process remains unexplained.

I have argued elsewhere in detail how the same reciprocal merging between a poem's narrator and a personified sea occurs when Walcott's poet/sailor persona closes "The Schooner Flight" with the admission that "Shabine sang to you from the depths of the sea" (see Hambuch 2015, 200). Not only does this line highlight a link to ancient storytelling traditions; it also lends both the storyteller and his environment the responsibility of preserving collective memory. I would like to emphasize with Sarah Nolan at this point that environment "is not only the "biological' aspect of a space but also the many cultural elements that compose it" $(2014,87)$. As I have argued in my essay on geo- and ecocritical considerations regarding Walcott's sea, the notion of a collective memory often evokes a distinct 
spirituality. The next, third section of the present essay focuses on "The Acacia Trees” from Walcott's last collection White Egrets. In the present section, though, I wish to draw attention to the closure of this poem. Much of White Egrets evokes a sense of looming mortality. It exhibits nuisances of old age, as well as grief for deceased friends. The final part of “The Acacia Trees" recalls such mourning of the dead, and offers comfort when the lyric I finds the voices of departed friends "in the page of a cloud, like the soft surf in [his] head" (Walcott 2010, 13). As in many other Walcott poems, nature symbolizes continuity in this conceit. His sense of continuity has as its starting point a Christian upbringing visible throughout his oeuvre, most prominently in references to Adam (Walcott 1986, 294), the Roseau Valley Church (319), the name of Achille's boat in Omeros ("In God We Troust"; Walcott 1990, 8), or a "fine Presbyterian / drizzle" in a poem dedicated to Lorna Goodison (Walcott 2010, 76).

While religious, albeit not spiritual, contexts are missing from Kirsch's poetry, Thani's does reveal his Islamic background. An explicit example from The Sand's Seat is the reference to the Qur'anic Surah 73 in the elliptical poem "Movement" (Thani 2010a, 55), a very short poem with much relevance for the present ecocritical analysis. As in Walcott's writing, the religious context often relates to ecopoetic representations of nature in Thani's. The poem "Movement" mentions the possibility of friendship with a tree (Thani 2010a, 54), and it ends with an appeal to a "fool." "You fool" - so the last two lines - "take enough sand / to build the sky" (56). The cosmic scope, including plants, sand, and sky, seen as well in "In This City," provides an additional parallel to Walcott's poetry. Thani was born in 1963 in Khorfakkan on the east coast of what would become the United Arab Emirates (New Writing from the Emirates 2011, 223). ${ }^{3}$ He moved to Al Ain as a student at the United Arab Emirates University. After his graduation, he worked as literary/ art critic for the Culture and Heritage Foundation in the country's capital, Abu Dhabi, until his premature death in 2012. Only eight years old in 1971, Thani witnessed the foundation of his country, which shares borders with Oman and Saudi Arabia, based on the union of seven sheikhdoms. Thani was among the founding members of the Emirates Writers' Union. Regrettably, very little of his work has so far become available in English. Besides poetry, he also wrote plays, literary criticism, and autobiographical prose.

Although his poetry shares Walcott's cosmic scope, religious contexts, and compelling expressions of "nature-centrism," it lacks Walcott's self-reflexive element. Among the three poets discussed here, Walcott is the only one to present leaves that are simultaneously those of a tree and a book, or the "page of

3 Al Rostamani (2012) cites 1962 as Thani's year of birth. 
a cloud" and "streets growing closer like print you can now read" (Walcott 2010, 89). The first two sections of the present comparative study have demonstrated an obsession with landscapes, seascapes, flora, and fauna shared by the three selected poets. The integration of human consciousness with the other-than-human, resulting in what Han, with Park, labels "nature-centrism," is more evident in texts by Walcott and Thani. The St Lucian and the Emirati poets further share a cosmic scope that seems derived from their respective religious backgrounds. Walcott adds a self-reflexive element to this scope, signalling a continuity of environment as well as of storytelling inspired by this environment. The German poet's Gothic aesthetics are of particular relevance to the next, third section, which discusses the ways in which all three make their concerns about human abuse of their environments explicit.

\section{Poetic representation of environmental threats: In lieu of doomed acres}

The 1992 Nobel laureate from St Lucia may be, at least in English-language criticism, the most famous of the three poets discussed here. Born in 1930, he also lived the longest life of the three. He published his last collection, White Egrets (2010), at eighty years of age. The most prominent book-length ecocritical study revolving at least partly around Walcott's poetry is George B. Handley's New World Poetics: Nature and the Adamic Imagination of Whitman, Neruda and Walcott (2007). Handley's ignorance of Bryson's pioneering Ecopoetry: A Critical Introduction (2002b) is especially disappointing because the latter includes an entire chapter on Walcott, Roy Osamu Kamada's "Postcolonial Romanticisms: Derek Walcott and the Melancholic Narrative of Landscape” (Kamada 2002). Handley's comparative study of three poets with different cultural identities, however, has still served as model for the present attempt to transfer his hemispheric or longitudinal approach onto a latitudinal, cross-continental angle.

The impact of colonialism on the Caribbean region, including the genocide of indigenous populations and the exploitation of natural resources are prominent themes throughout Walcott's work. The effects of these developments on the region's environments are self-explanatory. It is not surprising, therefore, that a considerable amount of ecocritical scholarship revolves around the Caribbean, among other postcolonial regions. The edited collection Caribbean Literature and the Environment: Between Nature and Culture (DeLoughrey, Gosson, and Handley 2005) and Elaine Savory's special issue of the Journal of West Indian Literature (Savory 2016) testify to these efforts. Omeros begins with a reference to trees that 
“have to die" (Walcott 1990, 3). This opening addresses Walcott's greatest environmental concern, the expansion of St Lucia's tourist industry. His character Helen, partly symbolizing the island, caters to this industry as a server, and as a souvenir vendor. White Egrets laments the unethical mechanisms of capitalism responsible for the industry's destructive impact in “The Acacia Trees.” This poem, already mentioned in the preceding section, employs an intriguing pun on "profit" and "prophet":

\author{
[...] I watched the doomed acres \\ Where yet another luxury hotel will be built \\ with ordinary people fenced out. The new makers \\ of our history profit without guilt \\ and are, in fact, prophets of a policy \\ that will make the island a mall [...] (Walcott 2010, 11)
}

Kirsch focuses less on the tourist industry and more generally on the endangered health of plants in industrialized environments. She responds to Goethe's ballad in the opening lines of "Watt III" [Mudflats III]. A speaker there introduces herself as the alder king's daughter, and claims to have a serious appointment with two apocalyptic equestrians in the mudflats ("Ich Erlkönigs Tochter habe eine / Ernsthafte Verabredung mit zwei / Apokalyptischen Reitern im Watt”; Kirsch 1992, 50). The reader imagines the equestrians as the father and son of Goethe's poem, but instead of the alder king, they are about to encounter one of his daughters in Kirsch's conceit. The poem does include a reference to a presumably drowned boy, corresponding to the death of the son in Goethe's rendering, which may explain the adjective "apocalyptic," but the entire setting suggests that this adjective applies more generally to the end of a polluted world. Notions such as "Möwenkadaver Colabüchsen" [seagull-corpse Coke cans] and the presence of a drilling rig add an environmentalist angle to the sense of an uncanny setting akin to the one Goethe created in the end of his ballad. Kirsch's closing lines depict crows falling as black apples from an isolated tree ("es fallen die Krähen / Schwarze Äpfel vom einzigen Baum"). Oil pollution further features in "Black Shoes" (Kirsch 1989, 35), and this is, understandably, also Thani's main environmental concern. The poem "From This Oil," indeed, exhibits a Gothic tone similar to that which can be discerned in Kirsch's texts. Seagulls are ripped apart, and the sky is screaming behind glass (Thani 2010a, 27-28). Waves are buried in walls, and dead blood on concrete is chasing dead air in the closing lines. These representations of ecological concerns do not dominate the work of any of the three poets discussed here, but their poignancy nevertheless warrants ecocritical readings of all their oeuvres alike. 


\section{Conclusion}

The ecopoetic elements examined in the preceding two sections of the present study tend to tackle the relationship between human (anthropocentric) nature and other-than-human (eco- or biocentric) nature. The analyses in the second section suggest that the poetry of Kirsch, Thani, and Walcott aims to focus on holistic syntheses that result in a nature-centrism that grants natural and cultural elements equal importance. Handley writes that "Walcott's poetry consistently searches for the merger between human and natural history" (Handley 2007, 296). The fact that Handley misses the extent to which much of Walcott's poetry succeeds in conveying a sense of $d o h$, becomes obvious in the following assessment of different crafts: "unlike fishing or harvesting, writing poetry is not an action that so directly and physically practices a nature-culture marriage but is rather a symptom of a divorce" $(2007,297)$. My readings in this comparative study, however, demonstrate an effective union involving the culture-related activity of creative expression as a nature-centric writing process. A closer look at ecopoetics may further support the claim of Lidström and Gerrard that "multiple and even contradictory levels of meaning" make poetry particularly conducive to ecocritical analysis (Lidström and Gerrard 2014, 37).

As my comparative analysis of work by the German Sarah Kirsch, the Emirati Ahmed Rashid Thani, and the St Lucian Derek Walcott demonstrates, even poets who are not the first to come to mind in the field of ecopoetics can contribute compellingly to it. The oeuvres of the three poets, who all died during the current decade, share an obsession with metaphors revolving around landscapes and seascapes. They further exhibit the human as an integral part of the otherthan-human, illustrating a distinct "nature-centrism." The three poets, finally, make their ecological concerns explicit in selected poems. In so doing, Kirsch and Thani employ a nightmarish tone, as is typical for Kirsch throughout her poetry collections. Thani and Walcott share a cosmic scope, to which Walcott adds a unique self-reflexive element. This self-reflexivity points to a certain continuity of nature. It evokes the concept of a never-ending story.

\section{Works cited}

Al Rostamani, Najla. “The Words and Works of Ahmed Rashid Thani." Gulf News 2 March 2012. https://gulfnews.com/opinion/thinkers/the-words-and-works-of-ahmad-rashid-thani1.988742 (9 October 2016).

Braziel, Jana Evans. “'Caribbean Genesis': Language, Gardens, Worlds (Jamaica Kincaid, Derek Walcott, Édouard Glissant)." Caribbean Literature and the Environment: Between 
Nature and Culture. Eds. Elizabeth DeLoughrey, Renée K. Gosson, and George B. Handley. Charlottesville: University of Virginia Press, 2005. 110-126.

Bryson, J. Scott. "Introduction." Ecopoetry: A Critical Introduction. Ed. Bryson. Salt Lake City: University of Utah Press, 2002a. 1-16.

Bryson, J. Scott, ed. Ecopoetry: A Critical Introduction. Salt Lake City: University of Utah Press, 2002b.

Butler, Michael. “'Die Endlichkeit dieser Erde ...': Sarah Kirsch’s Chronicles of Transience.” Contemporary German Writers: Sarah Kirsch. Eds. Mererid Hopwood and David Basker. Cardiff: University of Wales Press, 1997. 46-58.

DeLoughrey, Elizabeth, Renée K. Gosson, and George B. Handley, eds. Caribbean Literature and the Environment: Between Nature and Culture. Charlottesville: University of Virginia Press, 2005.

Fisher-Wirth, Ann, and Laura-Gray Street. “Editors' Preface.” The Ecopoetry Anthology. Eds. Fisher-Wirth and Street. San Antonio: Trinity University Press, 2015a. xxvii-xxxi.

Fisher-Wirth, Ann, and Laura-Gray Street, eds. The Ecopoetry Anthology. San Antonio: Trinity University Press, 2015b.

Glotfelty, Cheryl, and Harold Fromm, eds. The Ecocriticism Reader: Landmarks in Literary Ecology. Athens: University of Georgia Press, 1996.

Goethe, Johann Wolfgang von. “Der Erlkönig.” 1782. 19th-Century German Stories. Virginia Commonwealth University, n.d. https://germanstories.vcu.edu/goethe/erl_dual.html (8 June 2017).

Hambuch, Doris. "Geo- and Ecocritical Considerations of Derek Walcott's Multitasking, Omnipresent Sea." International Journal of Applied Linguistics and English Literature 4.6 (2015): 196-203.

Han, Jihee. “A Re-Reading of Yeats's Poems on Nature.” The Yeats Journal of Korea 37 (2012): 101-120.

Handley, George B. New World Poetics: Nature and the Adamic Imagination of Whitman, Neruda and Walcott. Athens: University of Georgia Press, 2007.

Heise, Ursula K. Sense of Place and Sense of Planet: The Environmental Imagination of the Global. Oxford: Oxford University Press, 2008.

Hopwood, Mererid. "Sarah Kirsch: Outline Biography." Contemporary German Writers: Sarah Kirsch. Eds. Hopwood and David Basker. Cardiff: University of Wales Press, 1997. 6-8.

Hopwood, Mererid, and David Basker, eds. Contemporary German Writers: Sarah Kirsch. Cardiff: University of Wales Press, 1997.

Kamada, Roy Osamu. "Postcolonial Romanticisms: Derek Walcott and the Melancholic Narrative of Landscape." Ecopoetry: A Critical Introduction. Ed. J. Scott Bryson. Salt Lake City: University of Utah Press, 2002. 207-220.

Kirsch, Sarah. Rückenwind. Munich: Deutsche Verlags-Anstalt, 1976.

Kirsch, Sarah. Erdreich. Munich: Deutsche Verlags-Anstalt, 1982

Kirsch, Sarah. Katzenleben. Munich: Deutsche Verlags-Anstalt, 1984.

Kirsch, Sarah. Schneewärme. Munich: Deutsche Verlags-Anstalt. 1989.

Kirsch, Sarah. Erlkönigs Tochter. Munich: Deutsche Verlags-Anstalt, 1992.

Lidström, Susanna, and Greg Garrard. "'Images adequate to our predicament': Ecology, Environment and Ecopoetics.” Environmental Humanities 5.1 (2014): 35-53. http:// environmentalhumanities.org/arch/vol5/5.3.pdf (20 May 2016).

New Writing from the Emirates. Issue of Banipal: Magazine of Modern Arab Literature 42 (2011). 
Nolan, Sarah. "Un-natural Ecopoetics: Natural/Cultural Intersections in Poetic Language and Form." New International Voices in Ecocriticism. Ed. Serpil Oppermann. Lanham: Lexington Books, 2014. 87-99.

Savory, Elaine, ed. Caribbean Ecocriticism. Spec. issue of Journal of West Indian Literature, 24.2 (2016).

Thani, Ahmed R. [ناني , أحمد ر.]. مقعد الرمل [The Sand’s Seat]. Abu Dhabi: ADACH, 2010 a.

Thani, Ahmed R. Das Meer gehörte einst mir. Trans. Suleman Taufiq. Basel: Lisan, 2010b.

Tiffin, Helen. “'Man Fitting the Landscape': Nature, Culture, and Colonialism.” Caribbean Literature and the Environment: Between Nature and Culture. Eds. Elizabeth DeLoughrey, Renée K. Gosson, and George B. Handley. Charlottesville: University of Virginia Press, 2005. 199-212.

Trende, Frank. “'Nö, ich will in keene Luxusstadt hocken' - im Urlaub nicht und sonst auch nicht: Ein nachgerufenes Nachwort.” AEnglish. By Sarah Kirsch. Munich: Deutsche Verlags-Anstalt, 2015. 69-80.

Walcott, Derek. Collected Poems, 1948-1984. London: Faber and Faber, 1986.

Walcott, Derek. Omeros. New York: Farrar, Straus and Giroux, 1990.

Walcott, Derek. White Egrets. London: Faber and Faber, 2010.

Wolting, Monika. Der Garten als Topos im Werk von Marie Luise Kaschnitz, Undine Gruenter und Sarah Kirsch. Wrocław: Wydawnictwo Uniwersytetu Wrocławskiego, 2009.

Doris Hambuch is associate professor in the Department of Languages and Literature at United Arab Emirates University. Her publications include essays on Caribbean literature, ecocriticism, film analysis, and transcultural feminism. She edited a special issue (6.2) of Imaginations: Journal of Cross-Cultural Image Studies on Caribbean cinema. Her current research focuses on Emirati cinema and ecopoetry. She serves as Vice President and Program Chair of the Canadian Comparative Literature Association. 